\title{
PT4 ENSAT Staging Finding v7
}

National Cancer Institute

\section{Source}

National Cancer Institute. pT4 ENSAT Staging Finding v7. NCI Thesaurus. Code C104022.

Adrenal cancer with tumor of any size. There is invasion of nearby org ans such as the kidney, pancreas, spleen or liver. (7th Ed, 2009) 